\title{
An arginine/ornithine exchange system in Spiroplasma melliferum
}

\author{
Idit Shirazi, Mark Tarshis and Shlomo Rottem
}

Department of Membrane and Ultrastructure Research, The Hebrew University-Hadassah Medical School, POB 12272, Jerusalem 91120 Israel
Author for correspondence: Shlomo Rottem. Tel: +9722 758 148. Fax: +972 2757413.

\begin{abstract}
Spiroplasma melliferum cells utilize arginine via the arginine dihydrolase pathway. L-Arginine uptake by intact cells was a saturable process both as a function of time and arginine concentration $\left(K_{m}=40 \mu \mathrm{M}\right)$. Uptake was not affected by $\mathrm{pH}$ in the range $\mathrm{pH}$ 5-0-8.0, or by L-citrulline, D-arginine, L-histidine or L-canavanine at concentrations tenfold higher than that of L-arginine. In contrast, L-arginine uptake was markedly inhibited by L-ornithine and partially inhibited by L-lysine. Uptake was neither affected by protonophores nor by cation ionophores, but was inhibited by protease treatment or by the sulfhydryl reagents $\mathbf{p}$-chloromercuribenzoate or $\boldsymbol{N}$-ethylmaleimide. Sealed membrane vesicles prepared by fusing isolated S. melliferum membranes with asolectin-cholesterol vesicles catalysed a rapid exchange $\left(t_{1}=1 \mathrm{~min}\right)$ between arginine and ornithine. Exchange did not require ATP and could be demonstrated in both directions, i.e. with either arginine or ornithine trapped within vesicles. These observations suggest that the driving forces for arginine uptake by whole cells are the concentration gradients of arginine and ornithine formed by arginine metabolism.
\end{abstract}

Keywords: mollicutes, Spiroplasma melliferum, arginine uptake, arginine/ornithine exchange

\section{INTRODUCTION}

The arginine dihydrolase pathway, widely distributed in prokaryotes, is a major pathway in many nonfermentative mollicutes acting as a source of energy and perhaps carbon and/or nitrogen (Barile et al., 1966; Miles, 1992). The enzymes of the pathway include arginine deiminase, which catalyses the irreversible conversion of arginine into citrulline and ammonia; ornithine carbamoyltransferase, which catalyses the phosphorolysis of citrulline yielding ornithine and carbamoylphosphate; and carbamate kinase, which converts carbamoylphosphate into $\mathrm{CO}_{2}$ and $\mathrm{NH}_{3}$ with concomitant phosphorylation of ADP to ATP (Cunnin et al., 1986). Spiroplasma species are helical mollicutes widely distributed in plants. Most spiroplasmas are fermentative (Whitcomb, 1980). Nevertheless, the presence of arginine deiminase activity, the absence of urease activity, and the increased concentrations of ornithine and citrulline as the degradation of arginine proceeds, also suggests the presence of the arginine dihydrolase pathway (Stevens et al., 1983; Miles,

Abbreviations: CCCP, carbonyl cyanide m-chlorophenylhydrazone; DCCD, dicyclohexylcarbodiimide; DES, diethylstilbestrol; NEM, $N$-ethylmaleimide; $\mathrm{PCMB}, p$-chloromercuribenzoate; SUV, single unilamellar vesicles.
1992). Therefore, arginine has been considered as an energy source for the growth of certain Spiroplasma species (Chang, 1989).

The cytoplasmic membrane of bacterial cells contains specific carrier molecules that allow the selective uptake and excretion of solutes. In most cases, these transport processes require metabolic energy (Krämer, 1994). However, the requirement may be overcome by linking substrate uptake to product excretion. For bacteria in which the conversion of $1 \mathrm{~mol}$ arginine to ornithine yields only $1 \mathrm{~mol} \mathrm{ATP}$, the idea of an exchange process requiring no metabolic energy is very attractive. Indeed, arginine/ ornithine exchange processes have been described in lactic acid bacteria (Driessen et al., 1987, 1989) and Pseudomonas aeruginosa (Verhoogt et al., 1992).

In the present study, we report for the first time the presence of an arginine/ornithine exchange mechanism in the arginine-utilizing mollicute Spiroplasma melliferum. The importance of this mechanism for the control of arginine metabolism is discussed.

\section{METHODS}

Growth conditions and cell preparation. Spiroplasma melliferum, strain BC 3, was obtained from Dr R. F. Whitcomb (USDA, Betsville, MD, USA). The organisms were grown in a 
medium consisting of $\left(\mathrm{l}^{-1}\right): 10 \mathrm{~g}$ peptone, $10 \mathrm{~g}$ tryptone, $7 \mathrm{~g}$ yeast extract and $2.5 \mathrm{~g}$ heart infusion broth (all from Difco), $70 \mathrm{~g}$ sorbitol (Sigma) and $2.5 \mathrm{~g} \mathrm{NaCl}$. The medium was supplemented with $20 \mathrm{mM}$ HEPES (Sigma), 4-10\% (v/v) heat inactivated horse serum and $10 \mathrm{mM}$ L-arginine and/or glucose. The $\mathrm{pH}$ of the medium was adjusted to $8 \cdot 0$. To label cell lipids, $\left[{ }^{3} \mathrm{H}\right]$ palmitic acid $\left(0.02-0.2 \mu \mathrm{Ci} \mathrm{m}^{-1}, 0.74-7.4 \mathrm{kBq} \mathrm{ml}^{-1} ; 55.8 \mathrm{Ci} \mathrm{mmol}^{-1}\right)$ was added to the growth medium (Razin \& Rottem, 1976). The medium was inoculated with $1-2 \%(v / v)$ inoculum, kept frozen at $-70{ }^{\circ} \mathrm{C}$ until use, and then grown without aeration for $24-48 \mathrm{~h}$ at $32{ }^{\circ} \mathrm{C}$. Growth was monitored by measuring the $\mathrm{OD}_{640}$ of the culture and by recording $\mathrm{pH}$ changes in the growth medium. Cells were harvested by centrifugation at $12000 \mathrm{~g}$ for $15 \mathrm{~min}$, washed twice with buffer $\mathrm{A}(0.25 \mathrm{M} \mathrm{NaCl}$, $10 \mathrm{mM} \mathrm{MgCl}$ and $20 \mathrm{mM}$ Tris/ $\mathrm{HCl}, \mathrm{pH} \mathrm{7 \cdot 5)}$ and resuspended in the same buffer containing $1 \%(\mathrm{w} / \mathrm{v})$ bovine serum albumin (BSA; Sigma). Cell membranes were isolated by osmotic lysis of the washed S. melliferum cells (Razin \& Rottem, 1976)

Preparation of hybrid membranes. Sealed hybrid membranes were prepared by fusion of isolated membrane preparations with lipid vesicles as described previousiy by Cirillo et al. (1987). In brief, single unilamellar vesicles (SUV) were prepared by sonication of a mixture of crude soybean phospholipids $(50 \mathrm{mg}$ asolectin $\mathrm{ml}^{-1}$, Sigma) in $0.25 \mathrm{M} \mathrm{NaCl}$ for $10 \mathrm{~min}$ using a W-350 Heat Systems ultrasonic disintegrator at $160 \mathrm{~W}$. A purified spiroplasma membrane preparation ( $1 \mathrm{mg}$ protein $\mathrm{ml}^{-1}$ ) was added to the SUV suspension ( $2 \mathrm{mg}$ lipids $\mathrm{ml}^{-1}$ ) and the mixture subjected to 2-3 cycles of freezing and thawing prior to sonication in a Branson bath ultrasonifier (model 1200) for 1-2 min. Sealing of hybrid membranes was checked by the retention of $\left[{ }^{14} \mathrm{C}\right]$ glucose (Cirillo et al., 1987). In brief, hybrid membranes containing $\left[{ }^{14} \mathrm{C}\right]$ glucose were incubated for various periods of time at $32{ }^{\circ} \mathrm{C}$, and $\left[{ }^{14} \mathrm{C}\right]$ glucose retained was calculated from the residual radioactivity after passing the membranes through Sephadex G-50.

Arginine uptake by cells. Spiroplasma cells ( $1 \mathrm{mg}$ protein) in buffer $A$ were preincubated for $5 \mathrm{~min}$ at $22^{\circ} \mathrm{C}$ in $1 \mathrm{ml}$ of a reaction mixture containing glucose $(10 \mathrm{mM})$, BSA $(1 \%)$, chloramphenicol $\left(100 \mu \mathrm{g} \mathrm{ml}^{-1}\right)$ and $0.2 \mathrm{mM}$ dithiothreitol. Arginine uptake by intact cells was initiated by adding $[2,3,4,5$ ${ }^{3} \mathrm{H}$ ]arginine monohydrochloride $\left(52.9 \mathrm{Ci} \mathrm{mmol}^{-1} ; 1957.3 \mathrm{GBq}\right.$ $\left.\mathrm{mmol}^{-1}\right)$ to a final concentration of $1.5 \mu \mathrm{Ci} \mathrm{m}^{-1}\left(55.5 \mathrm{kBq} \mathrm{ml}^{-1}\right)$ and unlabelled arginine to a final concentration of $0.2 \mathrm{mM}$. At various time intervals, $100 \mu$ l portions were withdrawn from the incubation mixture to a cold solution of $\mathrm{NaCl}(0.25 \mathrm{M})$ and subsequently filtered through Whatman GF/C fibreglass filters under negative pressure. The filters were washed twice with $10 \mathrm{ml}$ ice-cold $0.25 \mathrm{M} \mathrm{NaCl}$. Over $95 \%$ of the cells were retained on the filters as estimated by retention of $\left[{ }^{3} \mathrm{H}\right]$ palmitatelabelled cells.

Arginine uptake by hybrid membranes. Unlabelled L-arginine, L-lysine, L-ornithine or L-citrulline was entrapped in hybrid membranes by preparing the hybrid membranes in the presence of $2 \mathrm{mM}$ of the various solutes. The hybrid membranes were separated from the untrapped solute by passing $100 \mu$ samples through Sephadex G-50 in a $1 \mathrm{ml}$ tuberculin syringe as described elsewhere (Pick, 1981). The hybrid membranes were then rapidly diluted into $0.5 \mathrm{ml}$ incubation medium containing $1 \mu \mathrm{Ci}$ $(37 \mathrm{kBq})_{\mathrm{L}-}\left[{ }^{3} \mathrm{H}\right]$ arginine and incubated at $32^{\circ} \mathrm{C}$. At desired time intervals, samples $(75 \mu \mathrm{l})$ were withdrawn and filtered through $0.45 \mu \mathrm{m}$ cellulose nitrate filters (Schleicher and Schuell, Germany) presoaked with $20 \mathrm{mM}$ L-arginine. The filters were washed twice with $10 \mathrm{ml}$ ice-cold $0.25 \mathrm{M} \mathrm{NaCl}$, and the radioactivity retained on the filters measured.

Analytical methods. Protein in cell and membrane preparations was estimated by the Lowry method. ATP concentration was determined by the firefly luciferin method of Cole et al. (1967) after disruption of cells ( $0.5 \mathrm{mg}$ protein) by boiling for $2 \mathrm{~min}$ in $2 \mathrm{ml}$ deionized water. ATPase activity was determined as previously described by Shirazi \& Rottem (1994). Intracellular water volume was determined according to Rottem et al. (1981). In brief, cells, preincubated with ${ }^{3} \mathrm{H}_{2} \mathrm{O}$ and $\left[{ }^{14} \mathrm{C}\right]$ inulin, were pipetted onto the surface of silicone oil in Microfuge tubes and centrifuged at $12800 \mathrm{~g}$ for $2 \mathrm{~min}$. Under these conditions, the cells pass through the silicone oil and form a pellet at the bottom of the tube. The aqueous phase remains above the oil. Samples of the pellet and the aqueous phase were taken for radioactive analysis. ${ }^{3} \mathrm{H}_{2} \mathrm{O}$ was a measure of total pellet water, whereas $\left[{ }^{14} \mathrm{C}\right]$ inulin was a measure of intercellular space. The water space minus the inulin space was taken as the intracellular water space.

\section{RESULTS}

\section{Growth of spiroplasma in the presence of arginine}

Growth of $S$. melliferum cells is shown in Fig. 1. When both glucose and arginine were added to the medium, maximal growth was obtained after $36 \mathrm{~h}$ incubation at $32{ }^{\circ} \mathrm{C}$. A substantial $\mathrm{pH}$ drop was observed during the first $28-30 \mathrm{~h}$, then the $\mathrm{pH}$ began to rise, reaching $\mathrm{pH} 8$, a value close to that of uninoculated medium, after $48 \mathrm{~h}$ of growth. When the medium was supplemented only with glucose (Fig. 1), a lower extent of growth was observed, possibly because of the strong acidification of the medium. Compared to growth in medium with arginine and glucose, poor growth was observed when the growth medium was supplemented with arginine alone (Fig. 1) or in a medium without glucose or arginine (data not shown).

\section{ATP synthesis}

Arginine metabolism was also investigated by measuring intracellular ATP levels. Incubation of $S$. melliferum cells for $30 \mathrm{~min}$ at $32^{\circ} \mathrm{C}$ in buffer A markedly decreased ATP

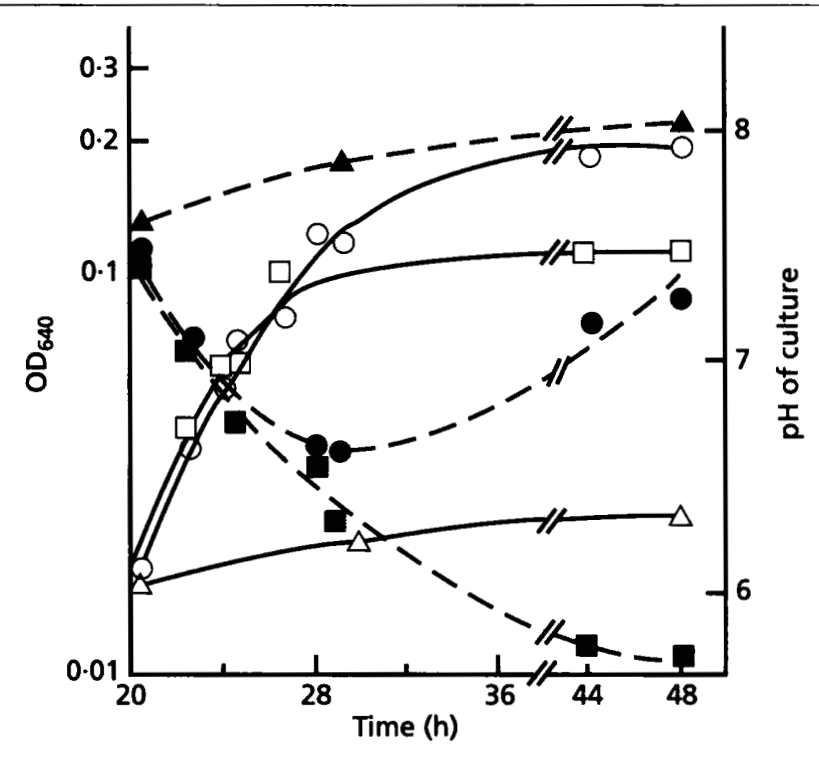

Fig. 1. Growth of S. melliferum in a medium containing $10 \mathrm{mM}$ arginine $(\triangle, \Delta)$, glucose $(\square, \square)$ or both $(O, 0)$. The $\mathrm{pH}$ (broken line, closed symbols) and $O D_{640}$ of the culture (solid line, open symbols) were measured. 


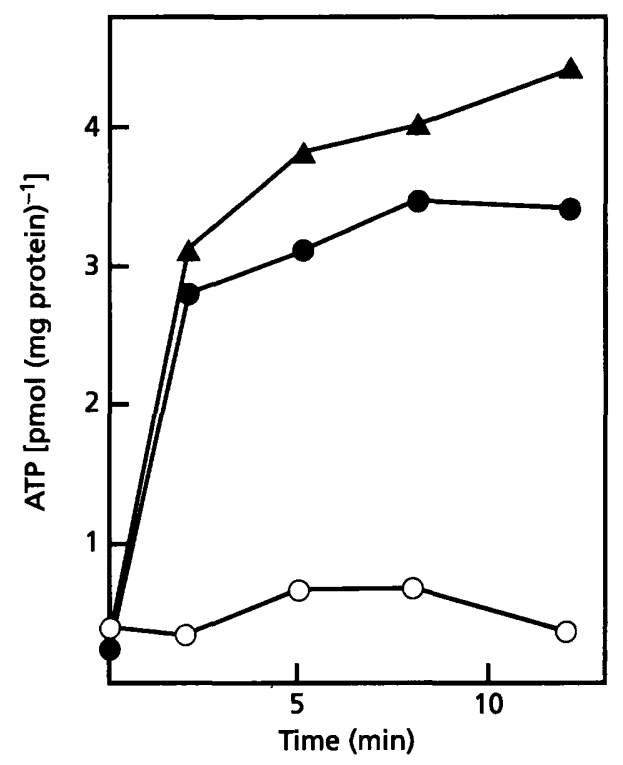

Fig. 2. ATP levels in S. melliferum cells, incubated in buffer $A$ without $(O)$ or with glucose $(\boldsymbol{A})$ or arginine (O). The cells were harvested, starved for $30 \mathrm{~min}$ at $32{ }^{\circ} \mathrm{C}$, and glucose or arginine $(20 \mathrm{mM})$ added.

levels, from 4-6 to about $0.4 \mathrm{pmol}$ ATP (mg cell protein $)^{-1}$. As seen in Fig. 2, when either arginine or glucose was added to energy-depleted cells at $32{ }^{\circ} \mathrm{C}$ the ATP level rapidly increased by approximately 15 -fold. The ATP levels obtained at $22^{\circ} \mathrm{C}$ (data not shown) were approximately $20 \%$ of those obtained at $32{ }^{\circ} \mathrm{C}$. The ability of $S$. melliferum to utilize arginine as an energy source was also indicated by experiments showing that, as for Spiroplasma floricola (Shirazi \& Rottem, 1994), S. melliferum cells extrude sodium ions by an energydependent process and that the energy requirement for this process could be fulfilled by either glucose or arginine (data not shown).

\section{Arginine uptake by intact $S$. melliferum cells}

L-Arginine uptake by $S$. melliferum cells was rapid and similar in mid-exponential phase cells grown either with glucose plus arginine or with glucose alone (Fig. 3). Uptake was not affected by substituting the sodium ions in the buffer system by equimolar amounts of potassium or choline ions (data not shown) or by varying the $\mathrm{pH}$ of the medium within a $\mathrm{pH}$ range of 5-8 (data not shown). However, arginine uptake was temperature-dependent (Fig. 3). No uptake was observed at $4{ }^{\circ} \mathrm{C}$. At higher temperatures, the initial rate of uptake increased reaching maximal levels at $32{ }^{\circ} \mathrm{C}$. Nonetheless, the levels obtained at $22{ }^{\circ} \mathrm{C}$ were relatively high, exhibiting $60-75 \%$ of the maximal uptake levels. Since at $22{ }^{\circ} \mathrm{C}$ arginine metabolism was much lower, the standard uptake assays were performed at $22^{\circ} \mathrm{C}$. Under these conditions, the uptake was linear for the first $2 \mathrm{~min}$. The kinetic parameters were determined from initial rates of uptake in buffer $A$ at arginine concentrations between $1 \mu \mathrm{M}$ and $500 \mu \mathrm{M}$. The

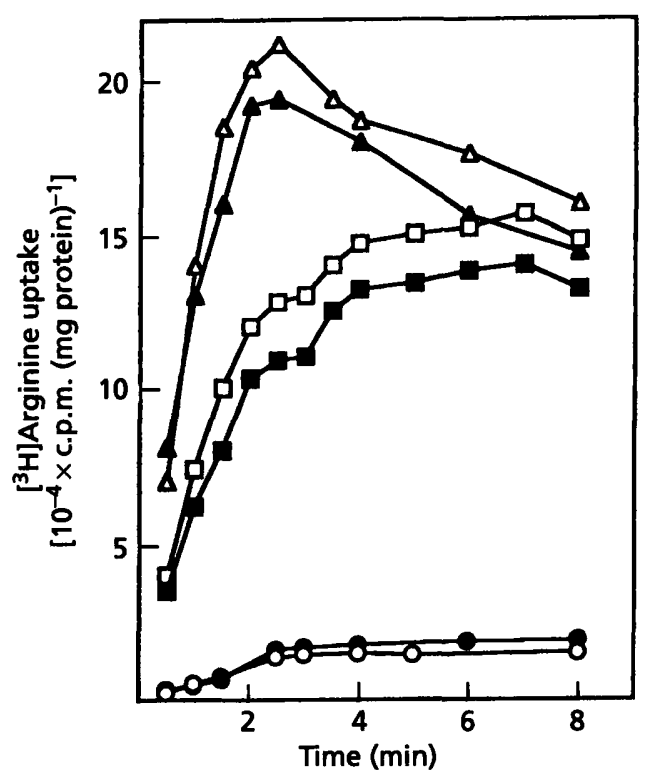

Fig. 3. Arginine uptake by whole $S$. melliferum cells, grown with glucose and arginine (open symbols) or with glucose alone (closed symbols), in buffer $\mathrm{A}$ at $4^{\circ} \mathrm{C}(\mathrm{O}, 0), 22^{\circ} \mathrm{C}(\square, \square)$ or $32^{\circ} \mathrm{C}(\triangle, \Delta)$.

Table 1. Effect of inhibitors on arginine uptake by S. melliferum cells

$\mathrm{L}-\left[{ }^{3} \mathrm{H}\right]$ Arginine uptake was determined at $22^{\circ} \mathrm{C}$ in buffer $\mathrm{A}$ adjusted to $\mathrm{pH} 7 \cdot 5$. Initial uptake rates are expressed as a percentage of that of a control (without inhibitor).

\begin{tabular}{|lcc|}
\hline Inhibitor & Concentration & $\begin{array}{c}\text { Initial uptake rate } \\
\text { (\% of control) }\end{array}$ \\
\hline CCCP & $10 \mu \mathrm{M}$ & 92 \\
SF.6847 & $0 \cdot 8 \mu \mathrm{M}$ & 98 \\
DCCD & $100 \mu \mathrm{M}$ & 89 \\
DES & $100 \mu \mathrm{M}$ & 97 \\
NEM & $2 \mathrm{mM}$ & 6 \\
pCMB & $2 \mathrm{mM}$ & 7 \\
Monensin & $5 \mu \mathrm{M}$ & 93 \\
Nigericin & $3 \mu \mathrm{M}$ & 89 \\
Valinomycin* & $5 \mu \mathrm{M}$ & 92 \\
Azide & $1 \mathrm{mM}$ & 100 \\
\hline
\end{tabular}

* Tested in buffer A containing $250 \mathrm{mM} \mathrm{KCl}$ instead of $\mathrm{NaCl}$.

uptake exhibited saturation kinetics. The apparent $K_{\mathrm{m}}$ value calculated from the Lineweaver-Burk plot was $40 \mu \mathrm{M}$ and the $V_{\max }$ was $0.45 \mathrm{nmol} \mathrm{L-arginine} \mathrm{accumu-}$ lated (mg cell protein $)^{-1} \mathrm{~min}^{-1}$.

\section{Inhibition of arginine uptake}

The protonophores carbonyl cyanide $m$-chlorophenylhydrazone (CCCP) or SF.6847 had almost no effect on $\mathrm{L}$ arginine uptake at $\mathrm{pH} 7 \cdot 5$ (Table 1$)$ or at $\mathrm{pH} 8 \cdot 0,7 \cdot 0$ or $6 \cdot 0$ 


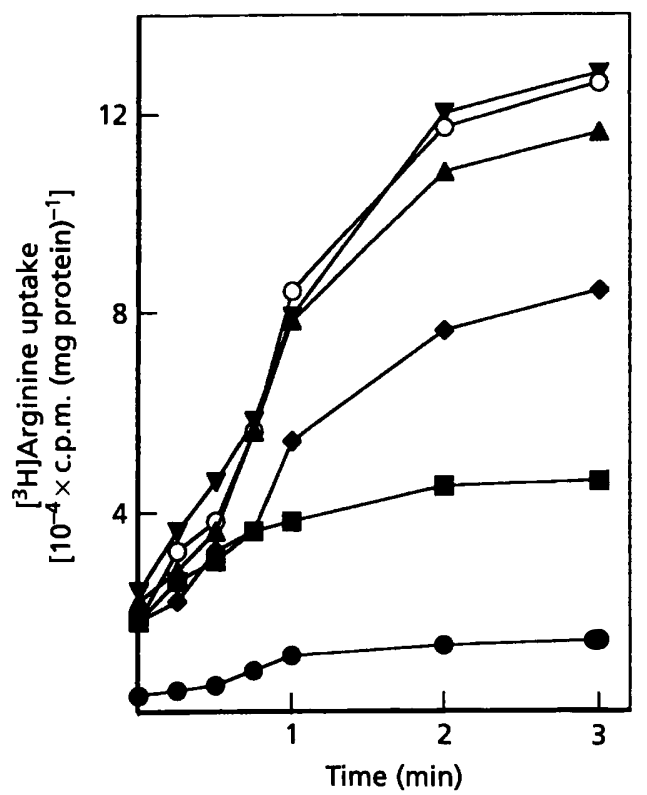

Fig. 4. Arginine uptake by whole $S$. melliferum cells suspended at $22^{\circ} \mathrm{C}$ in buffer $A$ in the presence of: $2 \mathrm{mM}$ lysine $(\bullet)$; citrulline $(\boldsymbol{\nabla})$; L-arginine $(O)$; D-arginine $(\boldsymbol{\Delta})$; ornithine $(\boldsymbol{D})$; buffer only (O). Unlabelled substances were added to the cell suspension 3 min before the L- $\left[{ }^{3} \mathrm{H}\right]$ arginine.

(data not shown). Arginine uptake was also little affected by the ionophores valinomycin $(1-5 \mu \mathrm{M})$, monensin $(0.5-5 \mu \mathrm{M})$ or nigericin $(1-3 \mu \mathrm{M})$ or by dicyclohexylcarbodiimide (DCCD) or diethylstilbestrol (DES), which inhibit the $\mathrm{H}^{+}$-translocating ATPase of spiroplasmas (Shirazi \& Rottem, 1994). In contrast, uptake was inhibited by the sulfhydryl-blocking reagents $p$-chloromercuribenzoate (pCMB) or $N$-ethylmaleimide (NEM) and was almost completely blocked (inhibition $>97 \%$ ) by treating the cells with protease $\mathrm{K}[20 \mu \mathrm{g}$ (mg cell protein) $)^{-1}$ for $15 \mathrm{~min}$ at $37^{\circ} \mathrm{C}$ ].
The specificity of the arginine uptake system was assessed from the extent of inhibition of $L-\left[{ }^{3} \mathrm{H}\right]$ arginine uptake by a tenfold excess of other basic amino acids or amines (Fig. 4). L-Canavanine did not affect arginine uptake (data not shown) and $\mathrm{D}$-arginine or L-citrulline inhibited arginine uptake by less than $15 \%$. However, inhibition by Lornithine was marked and similar to that caused by unlabelled L-arginine, suggesting that the system transports both L-arginine and L-ornithine. L-Lysine also significantly inhibited L-arginine uptake by an apparently variable extent (20-36\%, data not shown).

\section{Arginine/ornithine exchange in hybrid membranes}

Membrane preparations isolated from $S$. melliferum cells were leaky to trapped radioactive glucose (Table 2). However, when the membranes were fused with asolectin vesicles, a lower loss of $\left[{ }^{14} \mathrm{C}\right]$ glucose was observed after $2 \mathrm{~h}$ of incubation at $32{ }^{\circ} \mathrm{C}$, and inclusion of $50 \mathrm{~mol} \%$ cholesterol virtually eliminated leakage (Cirillo et al., 1987). Inclusion of cholesterol also resulted in a substantial increase in the volume of the hybrid membrane vesicles (Table 2). Therefore, in all experiments hybrid membranes were prepared by fusing $S$. melliferum membranes with SUV containing $50 \mathrm{~mol} \%$ cholesterol. The intact hybrid membrane vesicles showed a very low ATPase activity, $10-20 \%$ of the activity [ $420 \mathrm{nmol}$ ATP hydrolysed $\min ^{-1}$ (mg protein) ${ }^{-1}$ ] of hybrid membrane vesicles solubilized by $0 \cdot 1 \%$ Zwittergent 3-12.

When hybrid membrane vesicles were diluted into buffer A containing $\mathrm{L}-\left[{ }^{3} \mathrm{H}\right]$ arginine and incubated for up to $10 \mathrm{~min}$, arginine uptake was low or nonexistent (Fig. 5). However, uptake was rapid when hybrid membranes were preloaded with $2 \mathrm{mM}$ L-lysine or L-ornithine. The rate of arginine uptake observed with L-ornithine-loaded hybrid membrane vesicles was the same with hybrid membranes derived from glucose-grown cells and those derived from cells grown with both glucose and arginine (data not shown). Preloading hybrid membranes with

Table 2. Retention of radioactive glucose by sealed spiroplasma membrane/asolectin vesicle preparations (hybrid membranes)

$\left[{ }^{14} \mathrm{C}\right]$ Glucose retention [c.p.m. $\left.(\mathrm{mg} \text { protein })^{-1}\right]$ was determined at $32^{\circ} \mathrm{C}$. The free water volume of the hybrid membranes was measured at $2 \mathrm{~h}$ according to the method of Rottem et al. (1981).

\begin{tabular}{|c|c|c|c|c|}
\hline \multirow[t]{2}{*}{ Preparations } & \multicolumn{3}{|c|}{$\left[{ }^{14} \mathrm{C}\right] \mathrm{Glucose}$ retained after: } & \multirow{2}{*}{$\begin{array}{c}\text { Free water } \\
\text { volume }[\mu 1 \\
\left.(m g \text { protein })^{-1}\right]\end{array}$} \\
\hline & $\mathbf{O} \mathrm{h}$ & $1 \mathrm{~h}$ & $2 \mathrm{~h}$ & \\
\hline Membranes alone & 12800 & 9800 & 2600 & 0.5 \\
\hline $\begin{array}{l}\text { Membranes plus } \\
\text { asolectin vesicles }\end{array}$ & 44200 & 27200 & 21000 & 1.9 \\
\hline $\begin{array}{l}\text { Membranes plus } \\
\text { asolectin/cholesterol } \\
(25 \mathrm{~mol} \%) \text { vesicles }\end{array}$ & 67200 & 55400 & 39600 & $2 \cdot 9$ \\
\hline $\begin{array}{l}\text { Membranes plus } \\
\text { asolectin/cholesterol } \\
(50 \mathrm{~mol} \%) \text { vesicles }\end{array}$ & 114500 & 101500 & 77000 & $4 \cdot 9$ \\
\hline
\end{tabular}




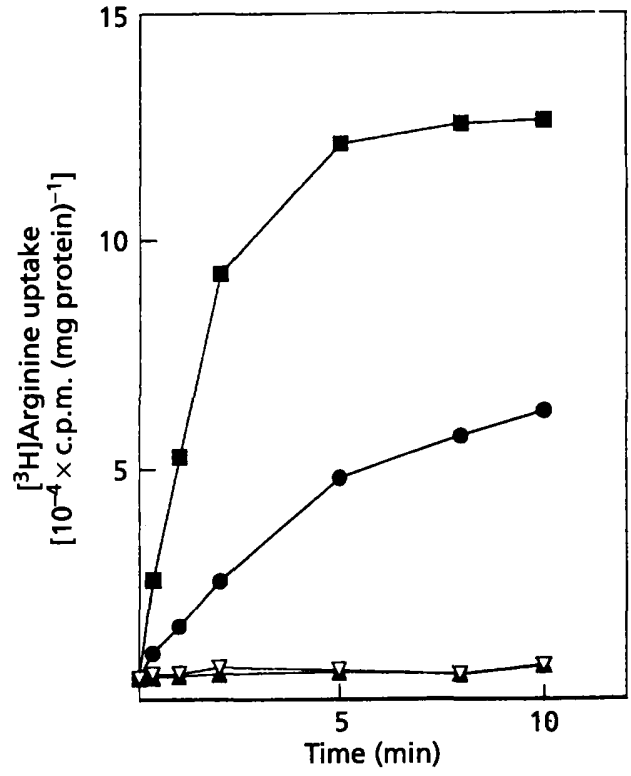

Fig. 5. L- $\left[{ }^{3} \mathrm{H}\right]$ Arginine transport at $32^{\circ} \mathrm{C}$ by hybrid membranes preloaded with buffer alone $(\nabla)$ or buffer containing $2 \mathrm{mM}$ unlabelled lysine (O), citrulline $(\boldsymbol{\Delta})$ or L- ornithine ( $\square$ ). Arginine uptake was initiated at zero time by a 50 -fold dilution of the loaded hybrid membranes into buffer A containing $\left[{ }^{3} \mathrm{H}\right]$ arginine.

$2 \mathrm{mM}$ L-citrulline or D-arginine did not stimulate uptake (data not shown). Ornithine-dependent L-arginine uptake was not affected by the uncoupler CCCP $(2-10 \mu \mathrm{M})$, by ionophores (nigericin, monensin or valinomycin; $0 \cdot 5-5$ $\mu \mathrm{M}$ of each) or by DCCD $(100 \mu \mathrm{M})$.

\section{DISCUSSION}

Arginine uptake by $S$. melliferum cells is a carrier-mediated process since the transport was saturable both as a function of time and arginine concentration and was inhibited by protease treatment or by treating the cells with sulfhydryl-blocking reagents. Furthermore, the process exhibited substrate specificity and stereospecificity for L-arginine. L-Ornithine and, to a lesser degree, L-lysine reduced the uptake rate, whereas $\mathrm{D}$-arginine or $\mathrm{L}$-citrulline were without effect. As we did not succeed in blocking the arginine dihydrolase pathway in intact cells, the uptake experiments with intact cells were carried out at a low temperature $\left(22{ }^{\circ} \mathrm{C}\right)$. Under these conditions, arginine metabolism was significantly decreased, whereas uptake was only slightly affected. Nonetheless, accurate estimate of the activity of the arginine/ornithine exchanger was possible only by the use of membrane vesicles.

Membrane vesicles are very convenient models for transport studies (Kaback et al., 1990). Unfortunately, membranes isolated from mollicutes do not form sealed membrane vesicles, as do many other bacterial membranes (Cirillo et al., 1987). To overcome this difficulty, we used a rather simple procedure where membrane fragments isolated from spiroplasma cells by osmotic lysis were fused with preformed asolectin vesicles by a freezing and thawing technique followed by a brief sonication (Pick, 1981). The hybrid membranes thus obtained were sealed, as demonstrated by the retention of radioactive glucose, and seem to have a right side out orientation since ATP added from the outside was inaccessible to the catalytic site of the membrane-bound $\mathrm{F}_{0} \mathrm{~F}_{1}$-ATPase located on the inner side of the membrane facing the cytoplasm (Futai \& Kanazawa, 1983).

Our results with both intact $S$. melliferum cells and hybrid membranes are in accordance with a precursor/product antiport system (Poolman, 1990), the antiporter catalysing both substrate (arginine) uptake and the extrusion of ornithine, the product of the arginine dihydrolase pathway. Since the substrate gradient is directed inward and that of the product outward, no metabolic energy is required for the exchange reaction, making it energetically favourable for an arginine-utilizing mollicute in which the conversion of $1 \mathrm{~mol}$ arginine to ornithine yields only 1 mol ATP (Barile et al., 1966). The hybrid membrane vesicles exhibited high arginine/ornithine exchange activity, but were unable to exchange arginine for citrulline (Fig. 5), enabling the cells to maintain the high citrulline concentration required to drive the reaction catalysed by ornithine carbamoyltransferase toward ornithine and carbamoylphosphate (Poolman et al., 1987).

Antiport systems reported in bacteria include the histidine/histamine exchanger of Lactobacillus buchneri (Poolman \& Konings, 1993), the lysine/alanine exchanger of Corynebacterium glutamicum (Bröer \& Krämer, 1990) and an arginine/ornithine exchange system described in Pseudomonas aeruginosa (Verhoogt et al., 1992) and Lactococcus lactis (Driessen et al., 1987). Like these antiporters, the arginine/ornithine exchange in $S$. melliferum has a relatively low affinity to its substrate with a $K_{\mathrm{m}}$ value of $40 \mu \mathrm{M}$. As both arginine and ornithine are positively charged at $\mathrm{pH} 7 \cdot 0$, the exchange is electroneutral. Exchange was not affected by the protonophores CCCP or SF.6847, which collapse the proton motive force, or by changing the charge within cells by treating them with valinomycin in the presence of high $\mathrm{KCl}$ concentrations. Uptake was similarly unaffected by monensin, which preferentially exchanges one sodium ion for one proton and has no effect on $\Delta \Psi$, and by nigericin, a nonelectrogenic antiporter that preferentially exchanges proton for potassium (Shirazi \& Rottem, 1994).

It has been previously suggested that the arginine/ ornithine antiporter of $L$. lactis is an inducible system (Driessen et al., 1987; Poolman \& Konings, 1993). The high activity of the arginine/ornithine exchange system and arginine dihydrolase in $L$. lactis cells grown in arginine-containing medium, and the low activity in cells grown with glucose, was interpreted as catabolite repression (Poolman et al., 1987). Our finding that a similar arginine uptake was observed with intact $S$. melliferum cells grown with or without added arginine suggests that in $S$. melliferum, the arginine/ornithine exchanger is constitutively expressed. Furthermore, the antiporter activity was the same with hybrid membranes containing 
membrane fragments isolated from cells grown with or without arginine. The constitutive nature of the arginine dihydrolase pathway in cells of another mollicute, Mycoplasma fermentans, has recently been demonstrated using a continuous perfusion ${ }^{13} \mathrm{C}-\mathrm{NMR}$ technology (Olson et al., 1993). Arginine utilization was the same in $M$. fermentans cells grown on an arginine-containing medium or on an arginine-deficient medium with glucose as an energy source (Olson et al., 1993). Furthermore, citrulline production by these cells was the same in the presence of glucose as in its absence, suggesting that glucose and arginine catabolic pathways in Mollicutes are independent of each other.

\section{ACKNOWLEDGEMENTS}

This study was supported by grant no. 1902-90R from the United States-Israel Binational Agricultural Research Development Fund.

\section{REFERENCES}

Barile, M. F., Schmike, R. T. \& Riggs, D. B. (1966). Presence of arginine dihydrolase pathway in Mycoplasma. J Bacteriol 91, 189-192.

Bröer, S. \& Krămer, R. (1990). Lysine uptake and exchange in Corynebacterium glutamicum. J Bacteriol 172, 7241-7248.

Chang, C.-J. (1989). Nutrition and cultivation of spiroplasmas. In The Mycoplasmas, vol. 5, pp. 210-241. Edited by R. F. Whitcomb \& J. G. Tully. New York: Academic Press.

Cirillo, V. P., Katzenell, A. \& Rottem, S. (1987). Sealed vesicles prepared by fusing $M$. gallisepticum membranes and preformed vesicles. Isr J Med Sci 23, 380-383.

Cole, H., Wimpenny, J. \& Hughes, D. (1967). The ATP pool in Eschericbia coli. I. Measurement of the pool using a modified luciferase assay. Biocbim Biophys Acta 143, 445-453.

Cunnin, R., Glansdorff, N., Pierard, A. \& Stalon, V. (1986). Arginine biosynthesis and metabolism in bacteria. Microbiol Rev 50, 314-352.

Driessen, A. J. M., Poolman, B., Kiewiet, R. \& Konings, W. N. (1987). Arginine transport in Streptococcus lactis is catalyzed by a cationic exchanger. Proc Natl Acad Sci US A 84, 6093-6097.

Driessen, A. J. M., van Leeuwen, C. \& Konings, W. N. (1989). Transport of basic amino acids by membrane vesicles of Lactococcus lactis. J Bacteriol 171, 1453-1458.
Futai, M. \& Kanazawa, H. (1983). Structure and function of proton translocating adenosine triphosphatase $\left(\mathrm{F}_{0} \mathrm{~F}_{1}\right)$ : biochemical and molecular biology approaches. Microbiol Rev 47, 285-312.

Kaback, H. R., Bibi, E. \& Roepe, P. D. (1990). Beta-galactoside transport in $E$. coli - a functional dissection of lac permease. Trends Biocbem Sci 15, 309-314.

Krämer, R. (1994). Systems and mechanisms of amino acid uptake and excretion in prokaryotes. Arch Microbiol 162, 1-13.

Miles, R. J. (1992). Catabolism in Mollicutes. J Gen Microbiol 138, 1773-1783.

Olson, L. D., Renshaw, C. A., Rottem, S. \& Boal, J. H. (1993). Arginine utilization by Mycoplasma fermentans is not regulated by glucose metabolism: a ${ }^{13} \mathrm{C}-\mathrm{NMR}$ study. FEMS Lett 108, 47-52.

Pick, U. (1981). Liposomes with a large trapping capacity prepared by freezing and thawing of sonicated phospholipid mixtures. Arch Biocbem Biophys 212, 186-194.

Poolman, B. (1990). Precursor/product antiport in bacteria. Mol Microbiol 4, 1629-1636.

Poolman, B. \& Konings, W. N. (1993). Secondary solute transport in bacteria. Biocbim Biopbys Acta 1183, 5-39.

Poolman, B., Driessen, A. J. M. \& Konings, W. N. (1987). Regulation of arginine-ornithine exchange and the arginine deiminase pathway in Streptococcus lactis. J Bacteriol 169, 5597-5604.

Razin, S. \& Rottem, S. (1976). Techniques for the manipulation of mycoplasma membranes. In Biochemical Methods in Membrane Studies, pp. 3-26. Edited by A. H. Maddy. London: Chapman and Hall.

Rottem, S., Linker, C. \& Wilson, T. M. (1981). Proton motive force across the membrane of Mycoplasma gallisepticum and its possible role in cell volume regulation. $J$ Bacteriol 145, 1299-1304.

Shirazi, I. \& Rottem, S. (1994). Volume regulation in Spiroplasma floricola: evidence that sodium is extruded by a sodium/proton antiport system. Microbiology 140, 1899-1907.

Stevens, C., Cody, R. M. \& Gudauskas, R. T. (1983). Effects of arginine on growth and in prolonging longevity of corn stunt spiroplasma in vitro. J Gen Appl Microbiol 29, 1-7.

Verhoogt, H. J. C., Smit, H., Abee, T., Gamper, M., Driessen, A. J. M., Haas, D. \& Konings, W. N. (1992). $\operatorname{arcD}$, the first gene of the arc operon for anaerobic arginine catabolism in Pseudomonas aeruginosa, encodes an arginine-ornithine exchanger. J Bacteriol 174, 1568-1573.

Whitcomb, R. F. (1980). The genus Spiroplasma. Annu Rev Microbiol 34, 677-709.

Received 25 January 1995; revised 19 April 1995; accepted 4 May 1995. 